\section{UJMM

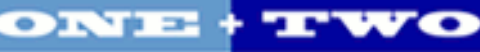

Volume 2 | 2009 Fall

\section{Undergraduate Journal of Mathematical}

Modeling: One + Two

2009

\title{
Call Forecasting for Inbound Call Center
}

Peter Vinje

University of South Florida

Advisors:

Arcadii Grinshpan, Mathematics and Statistics

Catrinia Hanlon, Accent Marketing

Problem Suggested By: Catrinia Hanlon

Follow this and additional works at: https://digitalcommons.usf.edu/ujmm

Part of the Mathematics Commons

UJMM is an open access journal, free to authors and readers, and relies on your support:

Donate Now

\section{Recommended Citation}

Vinje, Peter (2009) "Call Forecasting for Inbound Call Center," Undergraduate Journal of Mathematical

Modeling: One + Two: Vol. 2: Iss. 1, Article 7.

DOI: http://dx.doi.org/10.5038/2326-3652.2.1.7

Available at: https://digitalcommons.usf.edu/ujmm/vol2/iss1/7 


\title{
Call Forecasting for Inbound Call Center
}

\begin{abstract}
In a scenario of inbound call center customer service, the ability to forecast calls is a key element and advantage. By forecasting the correct number of calls a company can predict staffing needs, meet service level requirements, improve customer satisfaction, and benefit from many other optimizations. This project will show how elementary statistics can be used to predict calls for a specific company, forecast the rate at which calls are increasing/decreasing, and determine if the calls may stop at some point.
\end{abstract}

\section{Keywords}

Call Forecasting, Linear Regression, Extrapolation

\section{Creative Commons License}

(c) (i) (9)

This work is licensed under a Creative Commons Attribution-Noncommercial-Share Alike 4.0 License. 


\section{TABLE OF CONTENTS}

Problem Statement

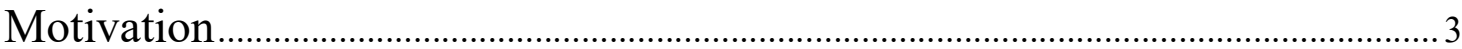

Mathematical Description and Solution Approach .....................................................

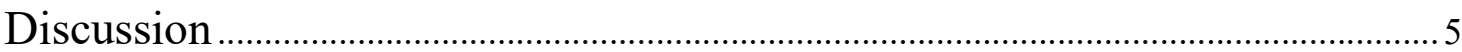

Conclusion and Recommendations......................................................................

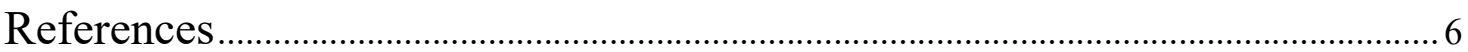

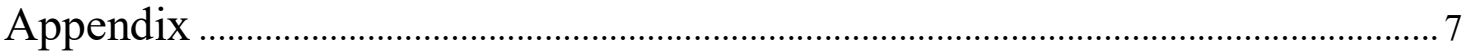




\section{PROBLEM STATEMENT}

The data provided in Table 1 was the template used to determine future trends and expectations. Other specific items that will be addressed include:

(1) Finding an expression that will represent the best line.

(2) Plotting the points on a graph and using the chart to determine what inferences can be made.

\section{MOTIVATION}

This project is a direct relationship to my job as an Assistant Program Manager in an Inbound Call Center. The ability to apply my calculus knowledge to this real life scenario allows me to retain the information much better than a traditional classroom learning environment.

\begin{tabular}{|c|c|}
\hline Date & Calls Handled \\
\hline Jan-08 & 93063 \\
Feb-08 & 83982 \\
Mar-08 & 81342 \\
Apr-08 & 82143 \\
May-08 & 77217 \\
Jun-08 & 76592 \\
Jul-08 & 81861 \\
Aug-08 & 76219 \\
Sep-08 & 71736 \\
Oct-08 & 71799 \\
Nov-08 & 61333 \\
Dec-08 & 64857 \\
Jan-09 & 68236 \\
Feb-09 & 62689 \\
Mar-09 & 65644 \\
Apr-09 & 55710 \\
May-09 & 53534 \\
Jun-09 & 56355 \\
Jul-09 & 60975 \\
Aug-09 & 58577 \\
Sep-09 & 56918 \\
Oct-09 & 54316 \\
Nov-09 & 40865 \\
\hline Table 1: Calls handled over a \\
23 month time period. \\
\hline
\end{tabular}

\section{MATHEMATICAL DESCRIPTION AND SOLUTION APPROACH}

For a set of $n$ points $\left(x_{1}, y_{1}\right), \ldots,\left(x_{n}, y_{n}\right)$ the linear least-square approximation is given by $y=\hat{\beta} x+\hat{\alpha}$ where

$$
\hat{\beta}=\frac{\sum_{i=1}^{n}\left(x_{i}-\bar{x}\right)\left(y_{i}-\bar{y}\right)}{\sum_{i=1}^{n}\left(x_{i}-\bar{x}\right)^{2}}
$$

and

$$
\hat{\alpha}=\bar{y}-\hat{\beta} \bar{x} .
$$


In the case of the call center data, the months must first be represented as numbers to obtain the $x$ values. For convenience, set Jan- $08 \rightarrow 1$, Feb- $08 \rightarrow 2, \ldots$, Nov- $09 \rightarrow 23$. Now

$$
\bar{x}=\frac{1}{23} \sum_{i=1}^{23} x_{i}=12 \quad \text { and } \quad \bar{y}=\frac{1}{23} \sum_{i=1}^{23} y_{i}=\frac{1,555,963}{23} \approx 67,650.6
$$

and using (1) and (2) the parameter values are calculated as

$$
\left\{\begin{array}{l}
\hat{\beta}=-1,746.6 \\
\hat{\alpha}=88,609.8
\end{array}\right.
$$

Now that the best linear approximation has been established, some justification for using a linear model is needed. For this, the sample correlation coefficient $R$ is calculated. Mathematically, the sample correlation coefficient is defined as the following:

$$
R=\frac{\sum_{i=1}^{n}\left(x_{i}-\bar{x}\right)\left(y_{i}-\bar{y}\right)}{\sqrt{\sum_{i=1}^{n}\left(x_{i}-\bar{x}\right)^{2}} \sqrt{\sum_{i=1}^{n}\left(y_{i}-\bar{y}\right)^{2}}}
$$

Geometrically, a data set with an $R$ of 1 or -1 may be fit exactly as linear function. These results are summarized below. When $R=0$, there is no linear correlation between the $x$ 's and $y$ 's. The sign of the sample correlation coefficient indicates whether the $x$ 's and $y$ 's have a positive or negative correlation. For the call center data,

$$
R=-\frac{883,781}{\sqrt{878,977,245,498}} \approx-0.9427
$$

which indicates that there is strong evidence for using the linear approximation. 


\section{DISCUSSION}

The following chart (Figure 2) was created in Excel and summarizes the statistics presented in the preceding section. Using the linear model $y=-1746 x+88610$, it is possible to forecast the future number of calls beyond the given data.

The reliability of this regression model is reinforced by the extreme correlation coefficient $R \approx-0.94$ calculated in (5). For a sample of size 23 , a correlation of $-1.0 \leq R \leq$ -0.5 is considered to be a strong negative correlation. The data clearly suggests that the number of inbound calls is strongly dependent on time and decreasing at a steady pace of around 1,746 calls per month. If this trend continues, the model predicts the center will stop receiving calls by March 2012. For further details, see Table 3 and Figure 4 in the Appendix.

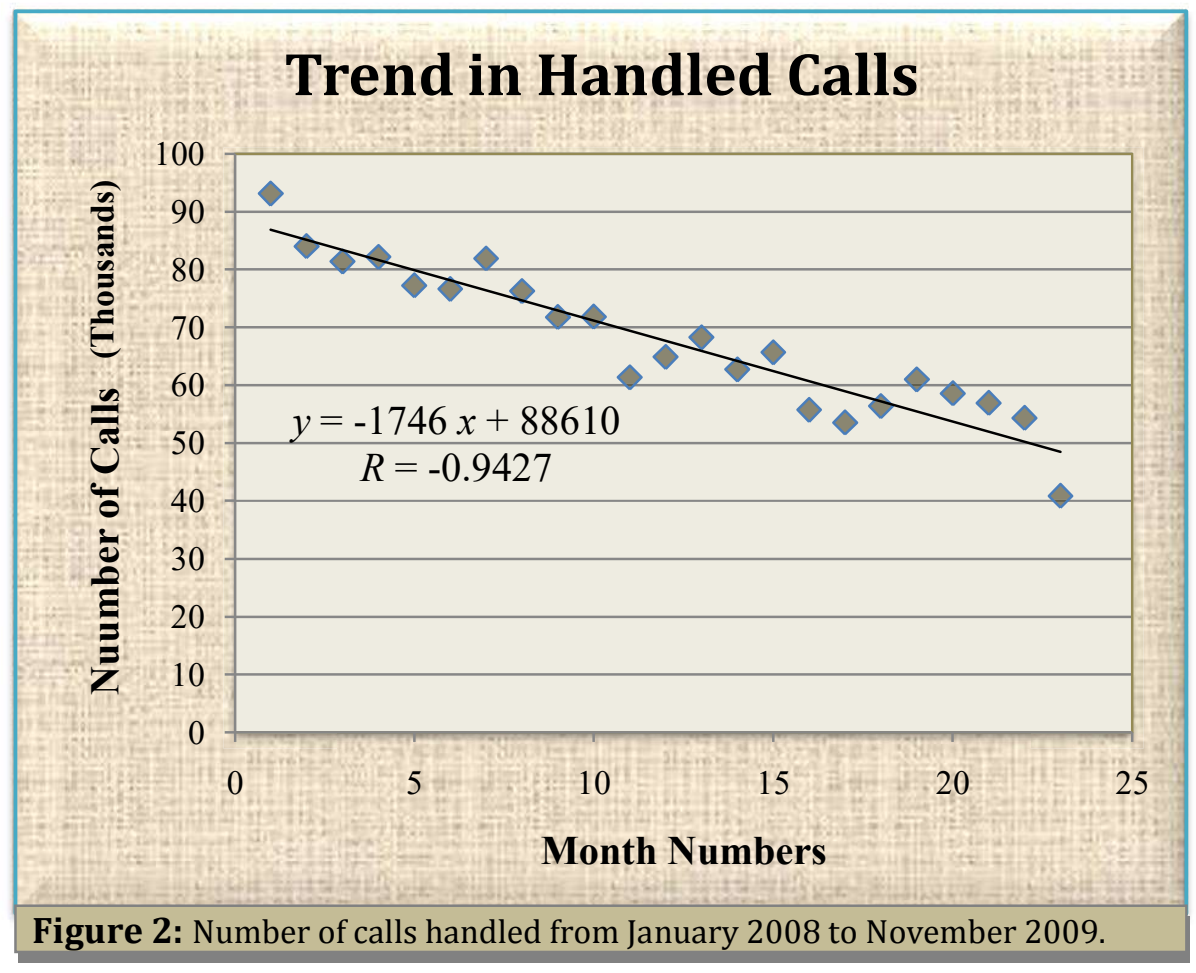




\section{CONCLUSION AND RECOMMENDATIONS}

The forecasting model created from the data confirmed both computationally and graphically that there is a simple linear relationship between time and the number of calls received by the inbound call center. By extrapolating this model, it was determined that the center would stop receiving calls by March 2012. If the business does not change this trend and increase the number of calls soon, there will not be a need for this call center.

\section{REFERENCES}

\section{WEB REFERENCE:}

http://www.weibull.com/DOEWeb/simple linear_regression_analysis.htm

\section{OTHER REFERENCES:}

- All charts and data were plotted using Microsoft Excel 2007.

- Workforce Manager and Catrinia Hanlon provided the data for the calls received. 


\section{APPENDIX}

\begin{tabular}{|c|c|c|c|}
\hline $\begin{array}{c}\text { Month } \\
\text { Number }\end{array}$ & $\begin{array}{l}\text { Month } \\
\text { Name }\end{array}$ & $\begin{array}{l}\text { Actual } \\
\text { Calls }\end{array}$ & $\begin{array}{c}\text { Estimated } \\
\text { Calls }\end{array}$ \\
\hline 1 & Jan-08 & 93063 & 86863.2 \\
\hline 2 & Feb-08 & 83982 & 85116.6 \\
\hline 3 & Mar-08 & 81342 & 83370.0 \\
\hline 4 & Apr-08 & 82143 & 81623.4 \\
\hline 5 & May-08 & 77217 & 79876.8 \\
\hline 6 & Jun-08 & 76592 & 78130.2 \\
\hline 7 & Jul-08 & 81861 & 76383.6 \\
\hline 8 & Aug-08 & 76219 & 74637.0 \\
\hline 9 & Sep-08 & 71736 & 72890.4 \\
\hline 10 & Oct-08 & 71799 & 71143.8 \\
\hline 11 & Nov-08 & 61333 & 69397.2 \\
\hline 12 & Dec-08 & 64857 & 67650.6 \\
\hline 13 & Jan-09 & 68236 & 65904.0 \\
\hline 14 & Feb-09 & 62689 & 64157.4 \\
\hline 15 & Mar-09 & 65644 & 62410.8 \\
\hline 16 & Apr-09 & 55710 & 60664.2 \\
\hline 17 & May-09 & 53534 & 58917.6 \\
\hline 18 & Jun-09 & 56355 & 57170.9 \\
\hline 19 & Jul-09 & 60975 & 55424.3 \\
\hline 20 & Aug-09 & 58577 & 53677.7 \\
\hline 21 & Sep-09 & 56918 & 51931.1 \\
\hline 22 & Oct-09 & 54316 & 50184.5 \\
\hline 23 & Nov-09 & 40865 & 48437.9 \\
\hline 24 & Dec-09 & - & 46691.3 \\
\hline 25 & Jan-10 & - & 44944.7 \\
\hline 26 & Feb-10 & - & 43198.1 \\
\hline 27 & Mar-10 & - & 41451.5 \\
\hline 28 & Apr-10 & - & 39704.9 \\
\hline 29 & May-10 & - & 37958.3 \\
\hline 30 & Jun-10 & - & 36211.7 \\
\hline 31 & Jul-10 & - & 34465.1 \\
\hline 32 & Aug-10 & - & 32718.5 \\
\hline 33 & Sep-10 & - & 30971.9 \\
\hline 34 & Oct-10 & - & 29225.3 \\
\hline 35 & Nov-10 & - & 27478.7 \\
\hline 36 & Dec-10 & - & 25732.1 \\
\hline 37 & Jan-11 & - & 23985.5 \\
\hline 38 & Feb-11 & - & 22238.9 \\
\hline 39 & Mar-11 & - & 20492.3 \\
\hline 40 & Apr-11 & - & 18745.7 \\
\hline 41 & May-11 & - & 16999.1 \\
\hline 42 & Jun-11 & - & 15252.5 \\
\hline 43 & Jul-11 & - & 13505.9 \\
\hline 44 & Aug-11 & - & 11759.3 \\
\hline 45 & Sep-11 & - & 10012.7 \\
\hline 46 & Oct-11 & - & 8266.1 \\
\hline 47 & Nov-11 & - & 6519.5 \\
\hline 48 & Dec-11 & - & 4772.9 \\
\hline 49 & Jan-12 & - & 3026.3 \\
\hline 50 & Feb-12 & - & 1279.7 \\
\hline 51 & Mar-12 & - & -466.9 \\
\hline
\end{tabular}

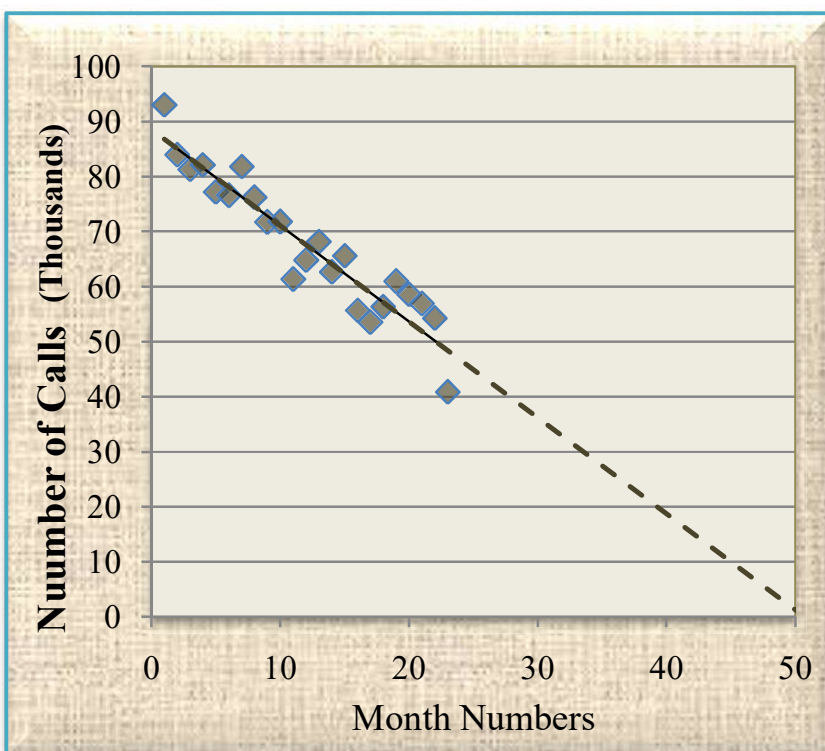

Figure 4: Projected trend for the next 27 months of calls received as predicted by the linear model. 